Article

\title{
Threshold Responses of Macroinvertebrate Communities to Stream Velocity in Relation to Hydropower Dam: A Case Study from The Guayas River Basin (Ecuador)
}

\author{
Thi Hanh Tien Nguyen ${ }^{1,2}$, Marie Anne Eurie Forio ${ }^{1, *}$, Pieter Boets ${ }^{1,3}$, , Koen Lock ${ }^{1}$, \\ Minar Naomi Damanik Ambarita ${ }^{1}$, Natalija Suhareva ${ }^{1,4}$, Gert Everaert ${ }^{1}$ (D), \\ Christine Van der heyden ${ }^{5}$, Luis Elvin Dominguez-Granda ${ }^{6}$, Thu Huong Thi Hoang ${ }^{7}$ \\ and Peter Goethals ${ }^{1}$
}

1 Laboratory of Environmental Toxicology and Aquatic Ecology, Ghent University, B-9000 Ghent, Belgium; hanhtienait8@gmail.com (T.H.T.N.); pieter.boets@oost-vlaanderen.be (P.B.), Koen_Lock@hotmail.com (K.L.); MinarNaomi.DamanikAmbarita@UGent.be (M.N.D.A.); natalija.suhareva@lhei.lv (N.S.); gert.everaert@vliz.be (G.E.); peter.goethals@ugent.be (P.G.)

2 Research Institute for Aquaculture No 1, Dinh Bang, Tu Son, Bac Ninh 220000, Vietnam

3 Provincial Centre of Environmental Research, Godshuizenlaan 95, B-9000 Ghent, Belgium

4 Latvian Institute of Aquatic Ecology, Voleru Street 4, Riga LV-1007, Latvia

5 Faculty of Sciences and Technology, Department of Nature and Food Sciences, University College Ghent, Valentin Vaerwyckweg 1, B-9000 Ghent, Belgium; christine.vanderheyden@hogent.be

6 Centro del Agua y Desarollo Sustentable, Facultad de Ciencias Naturales y Matemáticas, Facultad de Ingeniería Marítima, Ciencias Biológicas, Oceánicas y Recursos Naturales, Escuela Superior Politécnica del litoral (ESPOL), Campus Gustavo Galindo, km. 30.5 Via Perimetral, P.O. Box 09-01-5863, Guayaquil, Ecuador; ldomingu@espol.edu.ec

7 School of Environmental Science and Technology, Hanoi University of Science and Technology, No 1 Dai Co Viet, Hanoi, Vietnam, No 1 Dai Co Viet, Hanoi 100000, Vietnam; huong.hoangthithu@hust.edu.vn

* Correspondence: marie.forio@ugent.be; Tel.: +32-09-264-3708

Received: 24 July 2018; Accepted: 28 August 2018; Published: 6 September 2018

check for updates

\begin{abstract}
The Guayas River basin is one of the most important water resources in Ecuador, but the expansion of human activities has led to a degraded water quality. The purpose of this study was (1) to explore the importance of physical-chemical variables in structuring the macroinvertebrate communities and (2) to determine if the thresholds in stream velocity related to macroinvertebrate community composition could be identified in the Guayas River basin. Thus, macroinvertebrates and physical-chemical water quality variables were sampled at 120 locations during the dry season of 2013 in the Guayas River basin. Canonical correspondence analysis (CCA) was performed to identify relevant physical-chemical characteristics of the river influencing the distribution of the macroinvertebrate communities. Threshold indicator taxa analysis (TITAN) was used to discriminate between the macroinvertebrate community related to stagnant waters (Daule-Peripa reservoir) and to running waters. CCA indicates that the most important environmental factors influencing the distribution of macroinvertebrate communities were stream velocity, chlorophyll concentration, conductivity, temperature and elevation. Tipping points for the macroinvertebrate community were defined by stream velocity at $0.03 \mathrm{~m} / \mathrm{s}$ and $0.4 \mathrm{~m} / \mathrm{s}$, i.e., stagnant-water (including dam-related reservoirs) taxa start to quickly decrease in abundance and frequency at $0.03 \mathrm{~m} / \mathrm{s}$ while running-water taxa start to quickly increase in abundance and frequency at $0.03 \mathrm{~m} / \mathrm{s}$ until a stream velocity of $0.4 \mathrm{~m} / \mathrm{s}$. The results provide essential information to define environmental flows to further support water management plans of the Guayas River basin. Information obtained will be useful for management of similar rivers in South America, as well as the rest of the world.
\end{abstract}


Keywords: macroinvertebrates; water quality; stream velocity; Guayas River basin; TITAN; hydropower dams

\section{Introduction}

Rivers are ecosystems, which provide great ecological value [1]. They are an important source of renewable water supply for humans and freshwater ecosystems [2] and provide many ecosystem services such as sources of drinking water and recreational areas and provide nursing grounds and food for many organisms [3]. However, the increase in human activities such as industrialization, urbanization and intensive agriculture has caused river degradation [4]. Freshwater organisms are impacted via various stressors, such as water pollution, erosion, alterations in stream hydrology and changing habitat structures [5]. It is estimated that at least 10,000-20,000 freshwater species are extinct or at risk of extinction [2]. The water needs for human and natural ecosystems are often considered as competing with each other [6]. At the same time, water managers and political leaders need to manage water to meet human requirements, protect endangered species and support freshwater ecosystems [6].

There is an increasing interest in the application of ecological thresholds for natural resources management $[7,8]$. Baker and King [9] introduced a technique called threshold indicator taxa analysis (TITAN) to detect changes in taxa distributions along an environmental gradient over space or time. In previous studies, TITAN has been used to detect thresholds for benthic invertebrates along a gradient of chloride concentrations [10], salinity [11] and total phosphorus [9]. Berger et al. [3] used TITAN to look for the relationships between benthic invertebrates and various chemical variables related to pesticides, wastewater and fossil fuel-associated chemicals. Other TITAN applications include response analyses of macroinvertebrate communities to changes of the landscape [12]. However, to our knowledge, there is no research on detecting the critical change point of macroinvertebrate community composition along the change of stream velocity. Species-specific thresholds provide an indication of whether and when species are likely to be affected by changing environmental conditions [11]. TITAN reveals the ecological community threshold at which the abundance or frequency of taxa will quickly increase or decrease along an environmental gradient [13]. Therefore, from a conservation point of view, it is important to understand which taxa are affected by environmental stressors and how threshold values for river biota can be identified. Information about species and community thresholds is useful to further delineate the conservation value of a sensitive species or to predict the changes in community composition [11]. TITAN is able to inform managers about critical levels of anthropogenic changes that are related to rapid changes in ecological communities [13]. The TITAN results have valuable applications for detecting reference condition boundaries and selecting areas at the greatest risk of significant change [12]. This information could be used for aquatic conservation, biological invasions, ecosystem restoration and natural resource management [7].

The Guayas river basin is one of the most important river systems in Ecuador [14] and provides a high contribution to Ecuador's gross domestic income [15]. The Guayas basin is facing many water resource problems such as increasing modification of the natural flows by dams and water extractions for agriculture and urban water supply [16]. The intensive use of natural resources in the Guayas basin leads to exhaustion and disequilibrium of the ecosystem and the ecological integrity [17]. Because of the Daule-Peripa hydropower dam, discharge in the Daule river is highly variable. We expected that stream velocity plays a strong role affecting the macroinvertebrate community. However, the macroinvertebrate community of the Guayas River basin has been limitedly studied and research investigating the tipping point where species are likely to be affected by changing stream velocity is lacking. There is a strong need for information about how macroinvertebrate communities are affected by environmental stressors in the Guayas river basin in order to support the management for conservation and restoration of aquatic systems. Therefore, the aim of this study was to explore which physical-chemical water quality variables are most important in structuring 
macroinvertebrate communities. Furthermore, we checked whether thresholds in stream velocity related to macroinvertebrate community composition could be identified. These threshold values are needed in order to inform policy makers about critical levels of stream velocity, which can cause rapid changes in macroinvertebrate communities. The results provide useful information for prioritizing management actions in the Guayas River basin and it will be particularly useful for management of similar rivers in South America, as well as the rest of the world.

\section{Materials and Methods}

\subsection{Study Area}

The Guayas River basin, with a total area of $34,000 \mathrm{~km}^{2}$, is located in the central western part of Ecuador and is the largest watershed in the Guayas province [14]. The basin covers nine provinces with a total population of 4.8 million [14]. The eastern catchment boundary of the basin is the Andes. The Guayas River basin consists of two large tributaries: the Daule River and the Babahoyo River [14]. The two rivers converge in the Guayas River (Figure 1). The Guayas River is about $55 \mathrm{~km}$ in length, $1.5-3 \mathrm{~km}$ in width and 5-12 $\mathrm{m}$ deep [15]. The mouth is situated near Guayaquil, a city which is located along the Ecuadorian coast, where the river discharges into the Pacific Ocean at the Gulf of Guayaquil.

The main economic sectors of the Guayas River basin are hydropower, fisheries and agriculture (e.g., banana, rice, maize, African oil palm and cacao) [18]. These anthropogenic activities are key issues, which can lead to drastic changes in aquatic ecosystems and heavily impact the water quality of this river basin [19-21]. The lack of an appropriate management within the basin caused losses in biodiversity, eutrophication and reduced water availability [15].

The Daule-Peripa hydro-electrical project is located in the upper catchment of the Guayas River basin. The Daule-Peripa reservoir was constructed in 1987 and receives water from the Daule and Peripa Rivers [22] and is used for hydropower generation, irrigation, flood protection and drinking

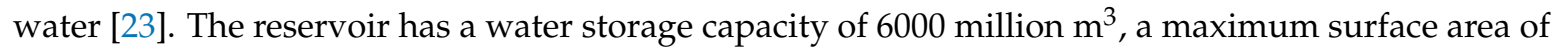
approximately 30,000 ha and the water depth fluctuates between 70 and $85 \mathrm{~m}$ due to the operation of the dam [24]. At the spillway of the dam, the maximum regulated flow is $3480 \mathrm{~m}^{3} / \mathrm{s}$ while the maximum natural flow is $14,350 \mathrm{~m}^{3} / \mathrm{s}$ [23]. Due to the operation of the dam, the Daule River transports significantly less water than the Babahoyo River [15]. Moreover, the dam caused reduction of the river discharge, causing narrowing of the channel and the unnatural formation and growth of islands at the confluence of Daule and Babahoyo River [15]. The seasons are well defined. Rainfall is concentrated in the wet season (December-April) and the dry season months are May-November [25]. The mean temperature and annual rainfall of the region vary between $22{ }^{\circ} \mathrm{C}$ and $27^{\circ} \mathrm{C}$ and $300-4000 \mathrm{~mm}$, respectively [17]. 


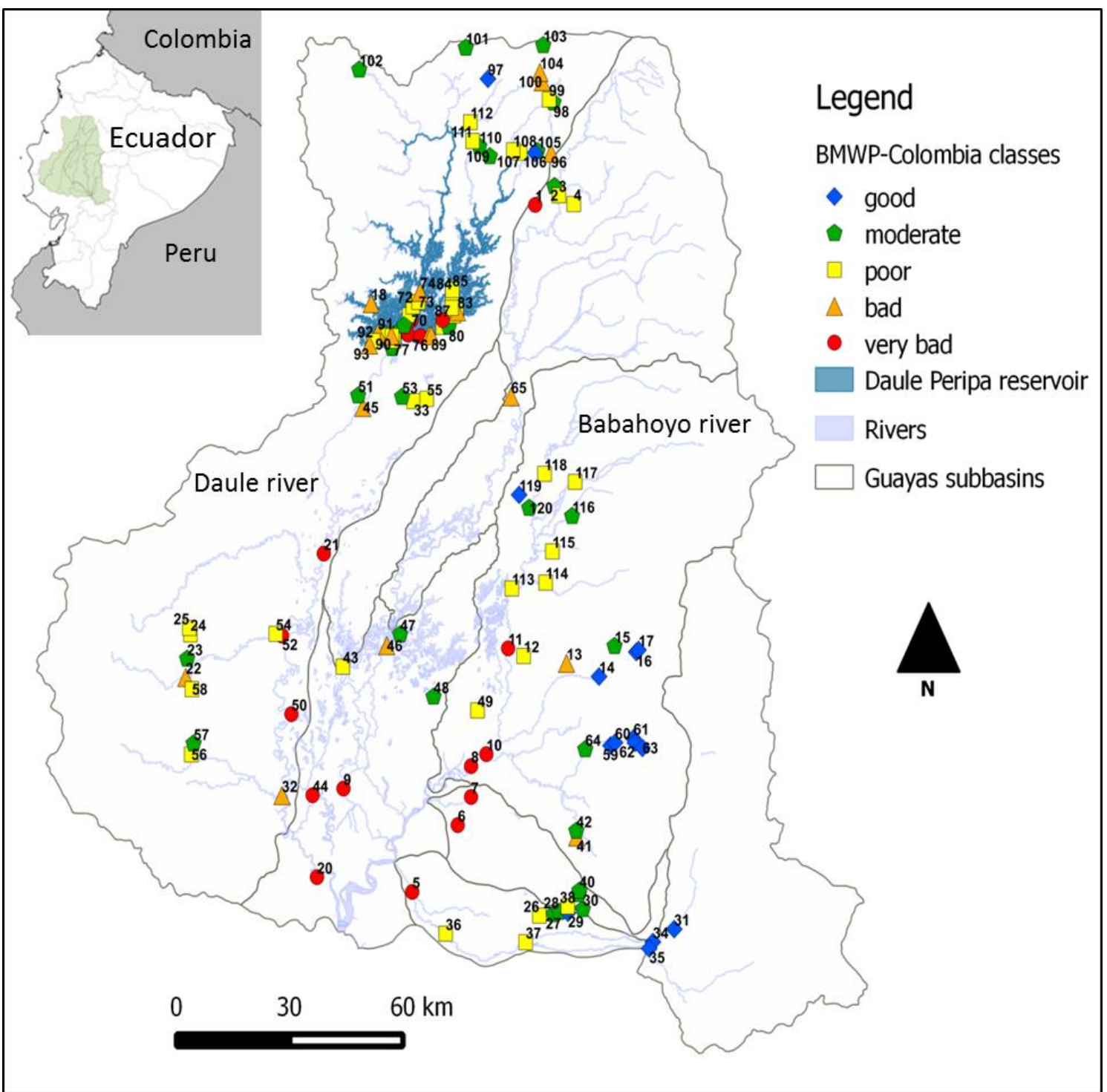

Figure 1. Map of the study area in the Guayas river basin with an indication of the ecological water quality based on the Biological Monitoring Working Party-Colombia (BMWP-Colombia) for each sampling site. Only the main rivers are shown.

\subsection{Sampling and Assessment Methods}

The physical-chemical water variables were measured and macroinvertebrates samples were collected in the Guayas river basin in Ecuador during the dry season (November) of 2013. Seasonality was considered when designing the sampling campaign. We assumed worst-case conditions in terms of water quality (e.g., conductivity) during the dry season, possibly accompanied by severe water quality problems. In total, 120 samples were taken, of which 32 were located in the Daule-Peripa reservoir and the remaining 88 locations were located along the rivers within the Guayas River basin, including upstream and downstream locations. The sites were selected along the Daule River, the Babahoyo River and at the main tributaries with an expected gradient of disturbance from upstream (mountainous areas with fewer human impacts) to downstream (lowland with more human impacts).

Values of temperature $\left({ }^{\circ} \mathrm{C}\right), \mathrm{pH}$, dissolved oxygen $(\mathrm{DO})(\mathrm{mg} / \mathrm{L})$, chlorophyll $(\mu \mathrm{g} / \mathrm{L})$, chloride $(\mathrm{mg} / \mathrm{L})$, turbidity (NTU), conductivity $(\mu \mathrm{S} / \mathrm{cm})$ and total dissolved solids (TDS) $(\mathrm{mg} / \mathrm{L})$ were measured at the surface water layer with a multiprobe (model YSI 6600 V2 and YSI6600 V1, YSI manufacturer). The elevation of sampling sites was measured using GPS (Global Positioning System) equipment (Garmin GPS). Surface water velocity was measured using the techniques for estimating stream velocity 
as described in the United States Environmental Protection Agency (USEPA) protocol. [26]. Samples of macroinvertebrates were collected from each sampling site immediately after the sampling of physical-chemical water variables. Macroinvertebrates were collected with a standard hand net consisting of a metal frame holding a $500 \mu \mathrm{m}$ mesh size conical net. Macroinvertebrates were collected during five minutes of active sampling, including all different microhabitats present at the sampling site [27]. Samples were sieved (500 $\mu \mathrm{m}$ mesh size) in the laboratory and sorted in white trays. Macroinvertebrates from each location were placed in separate small plastic vials containing $80 \%$ ethanol for preservation. After sorting, organisms were counted and identified under a stereomicroscope. Macroinvertebrates were identified to family level using the identification keys developed by Domínguez and Fernández [28]. Previous research has shown that using biotic indices based on family level provides sufficient information to assess the biological water quality [29-32]. It has been shown that macroinvertebrate-based indices better reflect water quality conditions compared to physical-chemical based indices [33]. Therefore, the biotic macroinvertebrate index BMWP-Colombia (Biological Monitoring Working Party-Colombia) was calculated according to the modified method proposed by Zuniga and Cardona (2009). The BMWP-Colombia was calculated per site based on a summation of all tolerance scores of the macroinvertebrate taxa present. Each macroinvertebrate taxon received a score that reflects its susceptibility to pollution, where pollution-intolerant taxa receive high scores, whereas pollution-tolerant taxa were given low scores [34]. The total score for each site indicated the water quality, with categories ranging from very bad (0-15), bad (16-35), poor (36-60), moderate (61-100) to good $(>100)$.

\subsection{Data Analysis}

All statistical analyses, including data exploration and model development were implemented in the R software (version 3.2.3, The R Project for Statistical Computing). A protocol for data exploration as described by Zuur et al. [35] was used. Prior to the actual data analysis, the initial data set was tested for outliers and normality. The Shapiro-Wilk test was used to check the normality of the data. As the data were non-normally distributed, the Spearman's correlation coefficient was used to investigate correlations between physical-chemical variables. Following the procedure suggested by Zuur et al. [35], TDS and $\mathrm{pH}$ were excluded from further analysis because they were highly correlated to conductivity and DO $(r=0.95, r=0.75$, respectively $)$ and to avoid problems of collinearity.

\subsubsection{Relationship between Physical-Chemical Conditions and Macroinvertebrate Communities}

Prior to the main analysis, detrended correspondence analysis (DCA) was performed to test the appropriate response model of the macroinvertebrate metrics to the environmental data. The first axis of the DCA gradient length was 4.71, which is more than three, therefore, the unimodal ordination method was used as recommended by Šmilauer \& Lepš [36]. A unimodal relationship was expected for macroinvertebrate taxa along the gradient defined by the explanatory environmental variables. The canonical correspondence analysis (CCA) is a constrained ordination technique, in which the response variable set is constrained by the set of explanatory variables [37]. CCA elucidates the relationships between macroinvertebrate assemblages and their environment and enables to extract environmental gradients [38]. Based on the gradients, the habitat preferences of taxa are described and visualized through an ordination diagram [38]. Thus, CCA was performed to explore which environmental variables could be important in structuring the macroinvertebrate communities in the Guayas River basin. One sampling location, where no macroinvertebrates were found, was excluded from DCA and CCA analysis. As the data were non-normally distributed, all data were $\log _{10}(x+1)$ transformed prior to the DCA and CCA analysis for normalization. DCA and CCA were performed using the vegan package [39] in R software (version R.3.2.3).

Subsequently, Kruskal-Wallis tests followed by Dunn's multiple comparisons test as post hoc were performed to test whether significant differences existed between the five ecological water quality classes for the variables that were important in structuring the macroinvertebrate communities based 
on the CCA (i.e., the variables elevation, temperature, conductivity, chlorophyll concentration and stream velocity). Dunn's test was used because there was an unequal number of sampling sites in different water quality classes [40]. The Dunn's test was performed using the DescTools package [41] in $\mathrm{R}$ software (version R.3.2.3). All tests were determined at the 5\% significance level. Boxplots were built for each variable as a function of BMWP-Colombia water quality classes.

\subsubsection{Threshold Change Points and Indicator Taxa}

Threshold indicator taxa analysis (TITAN) was used to detect community responses to stream velocity in the Guayas River basin. TITAN is a non-parametric technique, which uses indicator species scores to integrate occurrence, abundance and directionality of taxa responses.

For each value within this gradient, the data is split into two groups: one group consisting of taxa present at lower values (the so-called negative side of the partition, i.e., the (z-)-group) and one group consisting of taxa present at higher values (the so-called positive side of the partition, i.e., the ( $\mathrm{z}+$ )-group). For each taxon, an optimal change point is determined as the value that maximizes the association of taxa within both groups. When passing this change point from low to high values, the abundance and frequency of occurrence of the (z-)-group will decrease, while an increase will be observed for the $(\mathrm{z}+)$-group. To determine the accuracy of the change point value, bootstrapping (1000 repetitions) was implemented. This allowed to derive two important diagnostic indices for evaluating the quality of the response for each taxon: purity and reliability. Purity is defined as the proportion of response directions (increasing or decreasing) when passing the change point that agrees with the observed response. Pure indicators are consistently assigned the same response direction. Reliability is estimated by the proportion of change points that consistently result in the significant grouping of a taxon. Only taxa with high reliability $(\geq 0.95)$ can be considered as indicator taxa. Graphical representation of the change point identification is supported by the summation of the standardized association values for each indicator taxon along the gradient of stream velocity, resulting in fsum( $(z-)$ and fsum(z+) scores. Both scores will obtain a maximum value along the gradient of stream velocity, representing the change points for both the ( $\mathrm{z}-$ )-group and the $(\mathrm{z}+)$-group separately and can be defined as the community change point (of the considered taxa). TITAN was performed in the package TITAN 2 [42] in R software (version R.3.2.3).

In total, 83 macroinvertebrate taxa were found in 120 sampling sites within the Guayas river basin. Among these, 54 had five or more occurrences and were included in the TITAN analysis [43]. Taxa names which have more than eight characters were coded as eight character abbreviations of scientific names. Stream velocity was used as a predictor variable. Abundance data were not transformed because transformation is unnecessary in TITAN 2. Multiple permutations (e.g., 500 or 1000) are recommended in order to have more precise $z$ scores [42]. Thus, 1000 permutations were used to determine species-specific $z$ scores. We set as a requirement that the minimum number of observations on either side of any partition had to be $\geq 3$. Details of the TITAN method can be found in Baker and King [9], King and Baker [13] and Baker et al. [42].

\section{Results}

\subsection{Relationship between Physical-Chemical Conditions and Macroinvertebrate Communities}

Table 1 summarizes the physical-chemical water quality measured at 120 sampling locations within the Guayas river basin. The water was stagnant at all sampling sites in the Daule-Peripa reservoir. There was one sampling site located at the tributary of the Daule River, which had the highest observed values of DO $(13.6 \mathrm{mg} / \mathrm{L})$, chlorophyll $(66.8 \mu \mathrm{g} / \mathrm{L})$ and conductivity $(1981 \mu \mathrm{S} / \mathrm{cm})$. Conductivity values measured at all sampling sites at the Daule-Peripa reservoir were less than $110 \mu \mathrm{S} / \mathrm{cm}$. 
Table 1. Median, mean, maximum, minimum values and standard deviation of continuous environmental variables measured in the Guayas river basin.

\begin{tabular}{cccccc}
\hline Variable & Median & Mean & Max. & Min. & Std. \\
\hline Temperature $\left({ }^{\circ} \mathrm{C}\right)$ & 26.0 & 26.0 & 34.0 & 19.0 & 2.5 \\
$\mathrm{pH}$ & 7.6 & 7.7 & 8.9 & 6.6 & 0.5 \\
Dissolved Oxygen $(\mathrm{mg} / \mathrm{L})$ & 7.7 & 7.5 & 13.6 & 1.9 & 1.7 \\
Chlorophyll $(\mu \mathrm{g} / \mathrm{L})$ & 3.1 & 5.6 & 66.8 & 0.7 & 8.7 \\
Chloride $(\mathrm{mg} / \mathrm{L})$ & 2.5 & 7.3 & 181.7 & 0.5 & 22.8 \\
Turbidity $(\mathrm{NTU})$ & 3.4 & 9.8 & 355.6 & 0.0 & 35.1 \\
Conductivity $(\mu \mathrm{S} / \mathrm{cm})$ & 123.3 & 199.9 & 1981.0 & 36.5 & 237.9 \\
Total Dissolved Solids $(\mathrm{mg} / \mathrm{L})$ & 0.08 & 0.12 & 1.27 & 0.05 & 0.15 \\
Elevation $(\mathrm{m}$ a.s.l.) & 82 & 135 & 1075 & 2 & 187 \\
Stream velocity $(\mathrm{m} / \mathrm{s})$ & 0.15 & 0.23 & 1.50 & 0.00 & 0.28 \\
\hline
\end{tabular}

The first two ordination axes of the CCA analysis explained $45 \%$ and $22 \%$ of the total variance, respectively (Figure 2, Tables S1-S3). The lengths and positions of the arrows in the ordination diagram (Figure 2) provide information about the relationship between the environmental variables and the derived axes. The arrow length is proportional to the maximum rate of change in the value of the associated variable. Variables with long arrows vary across the diagram [38]. Arrows that are parallel to an axis (e.g., stream velocity and the first axis) indicate a correlation. The correlation between stream velocity and the first axis was positive while chlorophyll concentration and temperature were negatively correlated to the first axis (also shown by the direction of the arrows). Large positive scores on the first axis should have high values for stream velocity and low value for chlorophyll concentration, whilst large negative values on the first axis should have low values for stream velocity. Likewise, Perlidae and Psephenidae had high scores at the first axis. Thus, it is expected that Perlidae and Psephenidae were abundant at sites with high stream velocity and elevation. Furthermore, sampling sites located at the higher altitude have generally high stream velocity with fewer anthropogenic disturbances (i.e., low chlorophyll concentration and not turbid). Sampling sites with a high chlorophyll concentration, conductivity and temperature were collected at the downstream part of both the Daule and Babahoyo River (Figure 2). Moreover, the second axis was negatively correlated with conductivity. The few sampling sites at the small tributaries of both the Daule and Babahoyo River, which were almost dry, were characterized by a high conductivity. CCA analysis indicated strong associations between macroinvertebrate taxa and chlorophyll, conductivity, temperature, elevation and stream velocity (Table S3).

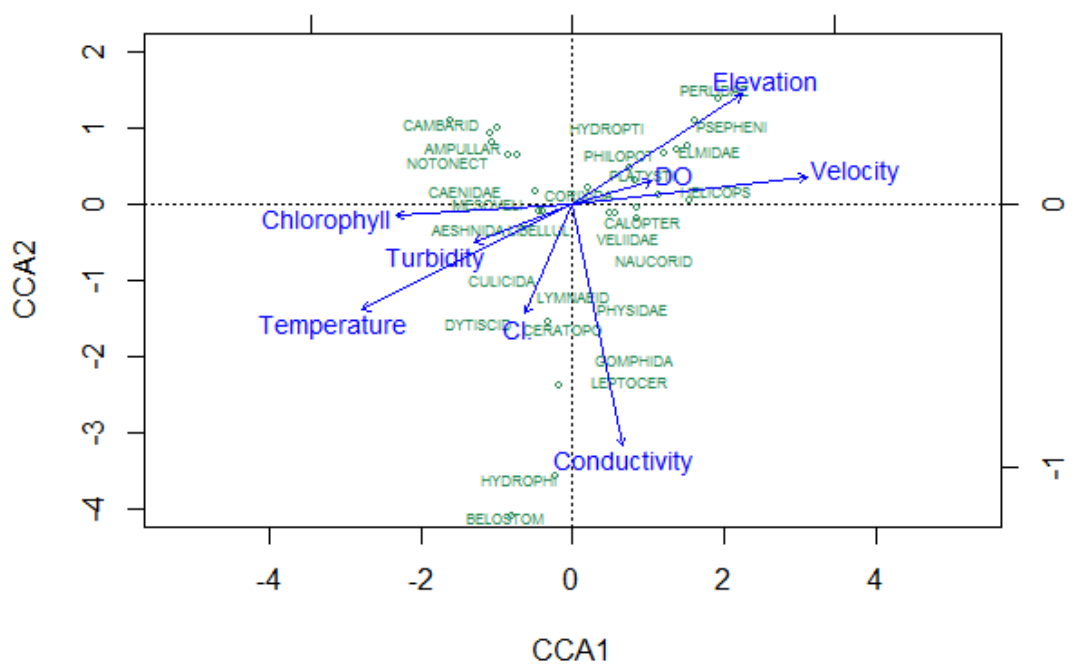

(A)

Figure 2. Cont. 


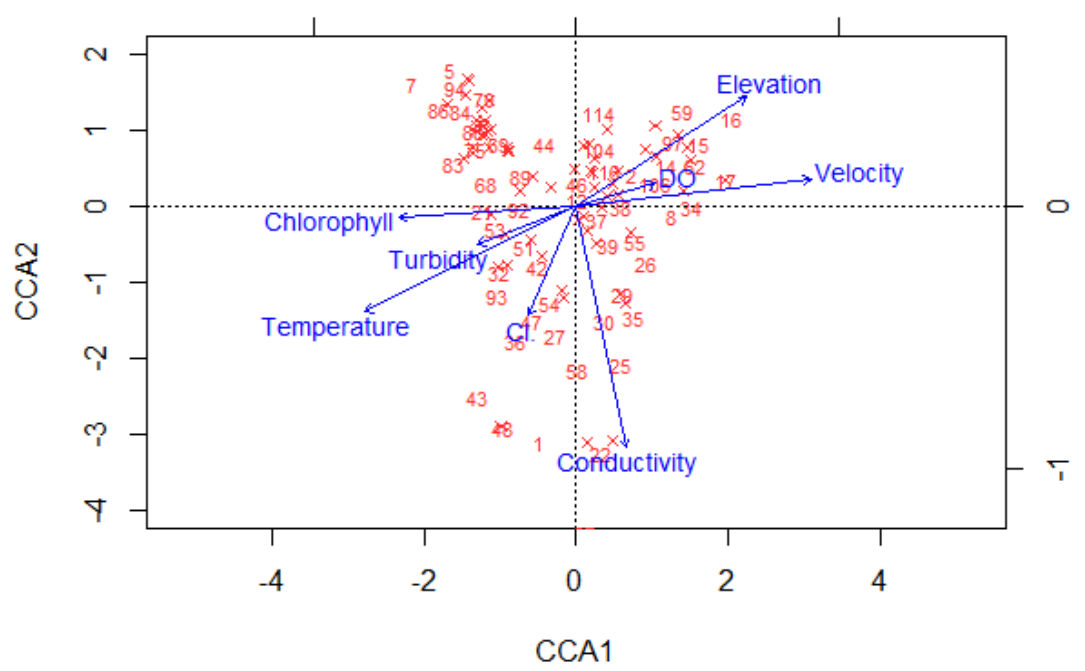

(B)

Figure 2. Canonical correspondence analysis (CCA) diagram showing the different macroinvertebrate taxa (A) or stations (B) and their correlation with environmental variables (blue vectors). Letters indicate taxa (see Table S4), numbers indicate sampling sites (see Figure 1).

Based on the BMWP-Colombia scores, the sampling sites within the Guayas River basin were categorized into five water quality classes: good, moderate, poor, bad and very bad (Figure 1). The result of the Kruskal-Wallis test shows that there was no significant difference in conductivity between different water quality classes $(p>0.05)$. However, there were significant differences in elevation, temperature, chlorophyll concentration and stream velocity between different water quality classes $(p<0.05)$. Good water quality was observed for sampling sites characterized by high elevations, high stream velocities, low temperatures and low chlorophyll concentrations $(p<0.05$; Figure 3$)$.
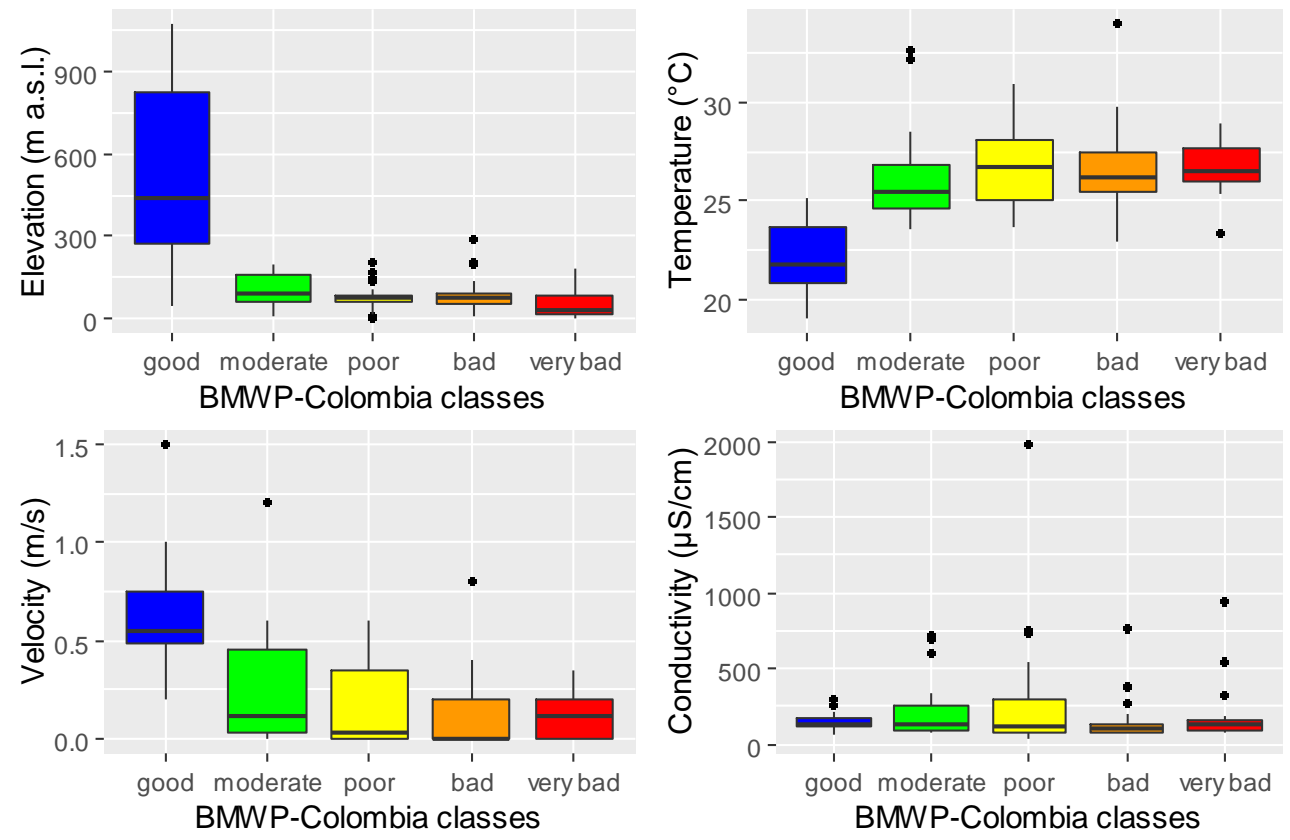

Figure 3. Cont. 


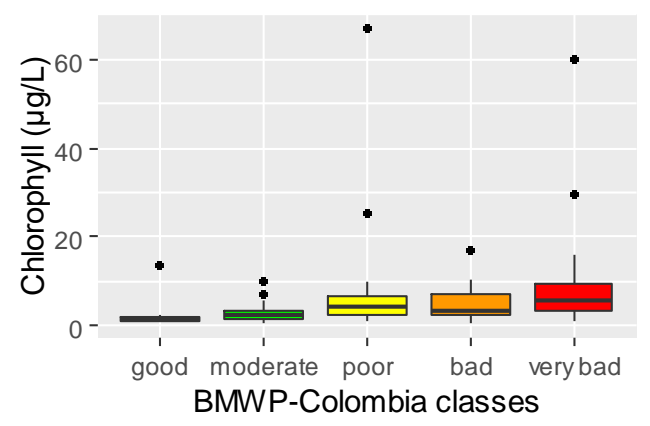

Figure 3. Boxplots of the different ecological water quality classes for the main environmental variables (elevation, temperature, stream velocity, conductivity and chlorophyll concentration) in the Guayas River basin. Bold horizontal lines represent median, boxes represent interquartile ranges (25-75\% percentiles) and range bars show maximum and minimum values, small black dots represent outliers.

\subsection{Threshold Change Points and Indicator Taxa}

Threshold indicator taxa analysis (TITAN) was implemented to test the macroinvertebrate community response to stream velocity in the Guayas river basin. The result of TITAN showed clear tipping points for the thresholds defined by stream velocity at $0.03 \mathrm{~m} / \mathrm{s}$ and $0.4 \mathrm{~m} / \mathrm{s}$. This indicates that stagnant-water taxa start to quickly decrease in abundance and frequency from $0.03 \mathrm{~m} / \mathrm{s}$ onwards while running-water taxa start to quickly increase in abundance and frequency from $0.03 \mathrm{~m} / \mathrm{s}$ until a stream velocity of $0.4 \mathrm{~m} / \mathrm{s}$. This is presented in Figure 4 (bottom). TITAN revealed 34 taxa (63\%) as reliable indicators of stream velocity, of which 20 taxa are indicated as indicators of high stream velocity and 14 taxa as indicators of low stream velocity in the Guayas river basin (Figure 4). Among the taxa that were indicators of high stream velocity were Leptophlebiidae, Calopterygidae, Leptohyphidae, Perlidae, Psephenidae, and Hydropsychidae while the taxa Hyallelidae, Notonectidae indicated low stream velocity in Figure 4 (top). 

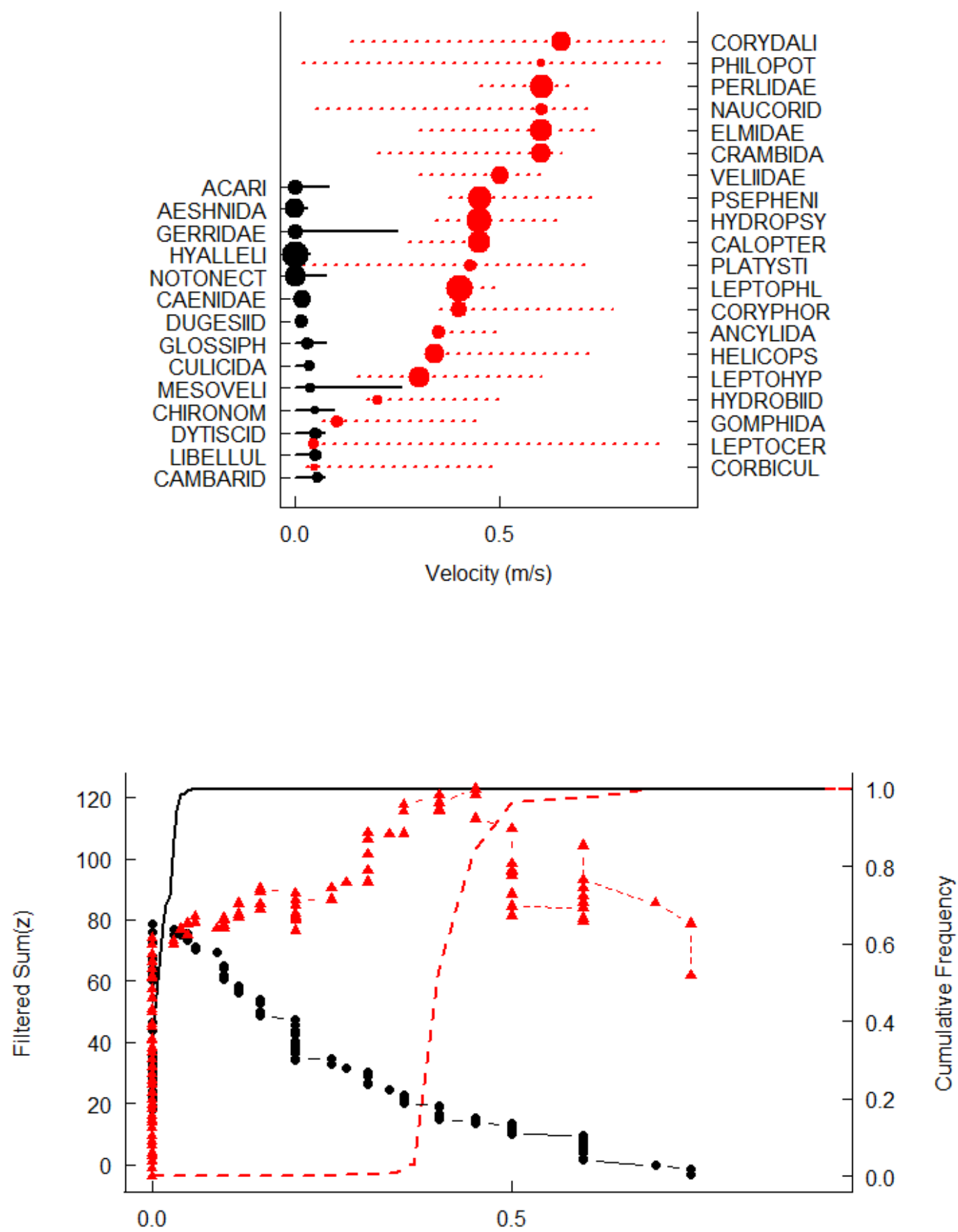

Velocity $(\mathrm{m} / \mathrm{s})$

Figure 4. Threshold indicator taxa analysis and change points (dots) for macroinvertebrate community response to stream velocity ( $p \leq 0.05$, purity $=0.95$, reliability $=0.95$ for five minimum number of observations, 1000 bootstrap and 1000 permutation replicates). Negative indicator taxa ( $\mathrm{z}-$ ) are indicated by black dots and lines and positive indicator taxa $(\mathrm{z}+)$ are indicated by red dots and dashed lines in the top figure. The size of change point symbol (dots) is proportional to the magnitude of the taxa response. $Z$ - species responded negatively to an increase in stream velocity, $Z+$ species responded positively to an increase in stream velocity. Horizontal lines in the top figure suggest $5-95 \%$ quantiles from the bootstrapped change point distribution. Black solid and red dashed lines in the bottom figure are cumulative frequency distributions of $\operatorname{sum}\left(z^{-}\right)$and $\operatorname{sum}\left(z^{+}\right)$maxima (respectively) across bootstrap replicates. Abbreviations and tabular results for individual taxa are presented in Table S4. 


\section{Discussions}

\subsection{Environmental Influences on the Macroinvertebrate Community}

According to the CCA results, there was a strong association between macroinvertebrate taxa and chlorophyll concentration, conductivity, stream velocity, temperature and elevation. This suggests an important linkage between physical-chemical variables and the macroinvertebrate community in the Guayas River basin. Our results show that good water quality was observed at sampling sites with a high elevation, low temperature, high stream velocity and low concentrations of chlorophyll. Those characteristics were observed at upstream sites, which have fewer human impacts. In general, water quality of rivers often deteriorates as one moves downstream due to the accumulating effects of different types of anthropogenic activities [44]. Low water quality was observed at sites with high chlorophyll concentrations and a high conductivity, which is likely related to damming, water extraction, intensive agriculture and urbanization in the Guayas River basin.

One of the stressors in the Guayas river basin is physical habitat alterations caused by stream velocity manipulation by the Daule-Peripa hydropower dam. Dams cause fluctuations in flow rate and accumulation of fine sediment within the reservoir [43]. Stream velocity and sediment substrate affect taxa distribution, abundance, richness and diversity [18], especially sensitive macroinvertebrate taxa [45]. It has been shown that changes in the flow regime due to water regulation and desiccation cause a significant reduction in macroinvertebrate density [46]. The results of our research are supported by previous relevant studies carried out from different locations with varying climatic and habitat conditions. For example, in Malaysian streams, stream velocity is one of the most important variable which influences macroinvertebrate diversity [47]. Moreover, Nelson and Lieberman [48] reported that stream velocity was the most important factor explaining the community composition of macroinvertebrates in the Sacramento River (California, USA). In the Kangaroo River (Australia), stream velocity was the most important characteristic affecting the spatial pattern of macroinvertebrate abundance and diversity [49].

Our study showed that sites with a good water quality have a median chlorophyll value of $1.7 \mu \mathrm{g} / \mathrm{L}$, a conductivity of $126 \mu \mathrm{S} / \mathrm{cm}$ and a stream velocity of $0.5 \mathrm{~m} / \mathrm{s}$. Algae are good bioindicators for eutrophication [50]. High chlorophyll concentrations can indicate the occurrence of algal blooms [51]. The growth of algae can provide evidence of eutrophication and degradation of water quality in streams and rivers [52]. In general, the conductivity values at sampling sites within the Guayas River basin are quite low (median $=123 \mu \mathrm{S} / \mathrm{cm}$ ), except for some locations that were almost dry. Low rainfall during the dry season causes a decrease in the water level and as a consequence, this may possibly promote water quality problems (e.g., little water remained and high conductivity values (for instance the maximum value was $1981 \mu \mathrm{S} / \mathrm{cm})$ ) at some sampling sites.

\subsection{The Threshold Responses of the Macroinvertebrate Community to Stream Velocity}

Based on the TITAN, we identified the tipping points for the thresholds defined by stream velocity at $0.03 \mathrm{~m} / \mathrm{s}$ and $0.4 \mathrm{~m} / \mathrm{s}$, i.e., stagnant-water taxa start to quickly decrease in abundance and frequency from $0.03 \mathrm{~m} / \mathrm{s}$ onwards while running-water taxa start to quickly increase in abundance and frequency at $0.03 \mathrm{~m} / \mathrm{s}$ until a stream velocity of $0.4 \mathrm{~m} / \mathrm{s}$. The TITAN method was only developed in 2010 and therefore, only a few studies used TITAN to detect thresholds for changes in macroinvertebrate community composition. We did not find other studies related to thresholds for stream velocity, thus, this research is probably the first that identified threshold responses of macroinvertebrates to stream velocity using threshold indicator taxa analysis. The results obtained during the present study are in accordance with previous studies. For instance, Theodoropoulos et al. [53] applied boosted regression tree models which revealed that high macroinvertebrate abundance and diversities were detected in flow velocities between $0.3 \mathrm{~m} / \mathrm{s}$ and $0.75 \mathrm{~m} / \mathrm{s}$. Moreover, the optimum stream velocity for certain macroinvertebrate taxa such as Baetis is $0.4 \mathrm{~m} / \mathrm{s}$ [54]. Furthermore, it was reported that at a 
stream velocity higher than $1 \mathrm{~m} / \mathrm{s}$, stream velocity acts as a constraint for most living organisms and the habitat is colonized only by species that tolerate such a high velocity [55].

TITAN revealed 34 taxa (63\%) as reliable indicators of stream velocity, of which 20 taxa are associated with a high stream velocity and 14 taxa are associated with a low stream velocity in the Guayas river basin. Everaert et al. [31] found that an increase in stream velocity was correlated with an increasing probability of occurrence of Leptophlebiidae in the Chaguana river basin in Ecuador. Our findings are in line with previous studies that the Leptophlebiidae were frequently living at stream velocities ranging from 0.36 to $0.80 \mathrm{~m} / \mathrm{s}$ and that increasing stream velocity is correlated to an increased abundance of mayflies (Leptophlebiidae) in the Bento Gomes River, Brazil [56]. We also found that high stream velocities are associated with numerous sensitive taxa, which is based on BMWP-Colombia scoring system, such as Perlidae and Psephenidae (tolerant scores 10), Leptoceridae (tolerant score 8) and Hydropsychidae (tolerant score 7). These results provide evidence for the possible influence of stream velocity on the macroinvertebrate community and the water quality.

TITAN revealed that 14 taxa such as Caenidae, Hyalellidae, Notonectidae, Dugesiidae and Glossiphoniidae displayed a negative response to an increasing stream velocity. When examining the habitat preferences for those taxa, the majority is strongly associated with vegetation (e.g., Notonectidae, Hyalellidae, Glossiphoniidae, Mesoveliidae, Aeshnidae, Libellulidae), bottom sediments (e.g., Hyalellidae) and shallow lakes (e.g., Dugesiidae, Gerridae, Mesoveliidae, Dytiscidae) [57]. The presence of these taxa could be attributed to the characteristics of the Daule-Peripa reservoir. In particular, it was reported that about one-third of the Daule-Peripa reservoir was invaded by water hyacinth (Eichhornia crasssipes) $[57,58]$. Caenidae are dominant in stagnant water [56]. Nelson and Lieberman [48] found the highest abundance of Chironomidae was observed at low velocities. Thus, the construction of the Daule-Peripa dam and its stream velocity manipulation can be one of the main causes of the presence of these taxa.

Case studies from neotropical regions (e.g., Bento Gomes River, Brazil) emphasized the seasonal discharge variation and stream velocity fluctuations affect macroinvertebrate (e.g., mayfly) assemblages [56]. Thus, further study over the wet and dry season is needed to have a full understanding of how the seasonal stream velocity differences affect the macroinvertebrate community in the Guayas River basin.

\subsection{Recommendations for River Management}

The decreasing ecological water quality within the Guayas River basin may be attributed to the modification of stream velocities (through damming and water abstraction), intensive agriculture and discharge of domestic wastewater without adequate treatment $[18,21,59]$. Other than the modification of stream velocities, agriculture and wastewater discharge are mainly related to the land use within the basin. Thus, in order to improve the biodiversity and water quality in the Guayas River basin, firstly, sustainable land management is required. It has been shown that land use has impacted the ecological quality within the Guayas River basin [19,21,59]. Land use within the Guayas River basin consists mostly of arable land, plantations (banana, rice, maize, African oil palm Elaeis guineensis and cacao), urban and semi-urban areas. Intensive agriculture often involves mono-cropping with high inputs of fertilizers, pesticides and herbicides [60], and may lead to ground water contamination and reduced biodiversity [61]. It has been shown that pesticides used in banana production [60] may enter watercourses and bring ecological risks to aquatic ecosystems [62]. Most of the agricultural and urban sites are located in the lowlands of the basin. The impacts of the activities accompanied by these land uses are reflected in the CCA wherein high turbidity and chlorophyll concentrations as well as low dissolved oxygen concentrations are evident at the lowland areas. High turbidity may be a result of erosion in agricultural areas while high chlorophyll concentration may be due to agricultural nutrient runoff. Low dissolved oxygen concentrations can be due to wastewater discharge in urban areas. Therefore, sustainable land use management can improve river water quality (e.g., reduce the chlorophyll concentration) by nutrient limitation [59] and reducing pesticide run-off into ecosystems. 
However, further studies regarding the impact of land use on water quality and macroinvertebrate community are needed.

Secondly, stream velocity has been shown to be an important parameter affecting the biological community. The stream velocity of the Guayas River basin can be managed by the Daule-Peripa dam. The Daule-Peripa dam was constructed for providing hydropower generation, irrigation, flood protection and drinking water [23]. The flow of the river is controlled by the dam for various purposes. During dam operation, the water is released, thus increasing the flow up to $110 \mathrm{~m}^{3} / \mathrm{s}$ [24] and causing a high stream velocity in the downstream river. Understanding the effect of variability in stream velocity on the macroinvertebrate community and the importance of this for the protection of freshwater biodiversity can provide basic information to define environmental flows. Dam managers can manipulate dam operating rules to maintain economic benefits while simultaneously conveying adaptive environmental flows for biodiversity [63]. Information about community thresholds, such as the one obtained in this study, can be used to adjust stream velocity levels for Ecuadorian rivers. Acreman \& Dunbar [64] suggested that defining the environmental flow is only one step in river protection; the natural flow of the river and flow needed to maintain for human needs (e.g., navigation, downstream uses) should also be considered [64]. The Guayas river basin needs to be better explored in order to improve knowledge regarding the impact of damming and other human activities on aquatic ecosystems. To our knowledge, no minimum stream velocity required to support aquatic life in the Guayas River basin has been determined.

Another potential option to improve the water quality is providing sanitation infrastructure (e.g., waste stabilization ponds and constructed wetlands) [65] in order to treat the wastewater before discharging it into the river. Although Ecuador has a legal water framework, no standards are available for chlorophyll concentration and conductivity. In Ecuador, water quality issues, aquatic ecosystems and ecosystem services have been receiving very limited attention [66]. Nevertheless, conductivity, chlorophyll concentration and stream velocity should be considered as important ecological drivers for the protection of the aquatic ecosystem in the Guayas River basin.

Community thresholds can link present conditions or predict the effect of environmental changes to community composition and thus can help to adjust approaches or prioritize locations of special conservation need [11]. Indeed, based on the patterns that are characterized in this research, novel management approaches can be developed and implemented. It might be useful to use TITAN to detect the thresholds for the response of each taxon and then building strategies to control the environmental variables in order to manage invasive taxa/species and to protect endangered species. This research may have important implications for future Ecuadorian environmental regulation. It has been known that macroinvertebrates are an important food source for numerous fishes $[67,68]$ while fishes serve as food not only for the locals but also for other organisms such as the birds; it is therefore of paramount importance to conserve macroinvertebrate communities. However, when extrapolating the results observed in this study to other similar river basins, it is needed to check whether the threshold responses of macroinvertebrates to stream velocities are consistent and applicable to these basins and to confirm the value of the TITAN approach for decision making. This approach gives a possibility to identify an optimal ecological flow, which will support a high biological diversity of the river.

\section{Conclusions}

In conclusion, this study provides additional information about the relationships between macroinvertebrates and environmental characteristics in the Guayas river basin. Chlorophyll concentration, conductivity and stream velocity are influential variables that need to be considered as important ecological drivers for macroinvertebrate communities. The findings of this study also provide clear tipping points in stream velocity. TITAN was able to discriminate between the macroinvertebrate community related to stagnant water (Daule-Peripa reservoir) and the macroinvertebrate community related to running waters. The results of this study indicate the 
importance of multiple factor assessments for reliable predictions of macroinvertebrate responses. Although it may be emphasized that it is important to identify threshold responses to stream velocity, these thresholds must be combined with the results of key environmental variables in order to define the ecological flow and conserve biodiversity.

Supplementary Materials: The following are available online at http://www.mdpi.com/2073-4441/10/9/1195/s1. Table S1: Results of CCA analysis; Table S2: Accumulated constrained eigenvalues; Table S3: Biplot scores for constraining variables. Biplot scores higher than 0.6 are indicated in bold; Table S4: Threshold Indicator Taxa Analysis of individual taxa in response to stream velocity $(\mathrm{m} / \mathrm{s})$ in the Guayas River basin.

Author Contributions: T.H.T.N. did the literature study, analysed the data and wrote the work. M.A.E.F., P.B., K.L., M.N.D.A., N.S., G.E., C.V.D.H., L.E.D.-G., T.H.T.H. and P.L.M.G. edited the work. T.H.T.N., M.A.E.F., K.L., M.N.D.A., N.S., C.V.D.H., L.E.D.-G., P.L.M.G. collected the data. K.L. identified the macroinvertebrates. M.A.E.F. revised the work and P.L.M.G. initiated the study and supervised the work overall.

Funding: This research received no external funding.

Acknowledgments: This research was performed in the context of the VLIR Ecuador Biodiversity Network project. This project was funded by the Vlaamse Interuniversitaire Raad-Universitaire Ontwikkelingssamenwerking (VLIR-UOS), which supports partnerships between universities and university colleges in Flanders and the South. The first author is grateful for the financial support for this work from the Belgian Technical Cooperation (BTC) in the framework of her Ph.D. grant. Marie Anne Eurie Forio and Minar Naomi Damanik-Ambarita received financial support from the Special Research Fund of Ghent University. Gert Everaert is supported by a post-doctoral fellowship from the Special Research Fund of Ghent University (BOF15/PDO/061). We would like to thank CADS-ESPOL for the help during the fieldwork.

Conflicts of Interest: The authors declare no conflict of interest.

\section{References}

1. Benetti, C.J.; Perez-Bilbao, A.; Garrido, J. Macroinvertebrates as indicators of water quality in running waters: 10 years of research in rivers with different degrees of anthropogenic impacts. Ecol. Water Qual. Water Treat. Reuse 2012.

2. Vorosmarty, C.J.; McIntyre, P.B.; Gessner, M.O.; Dudgeon, D.; Prusevich, A.; Green, P.; Glidden, S.; Bunn, S.E.; Sullivan, C.A.; Liermann, C.R.; et al. Global threats to human water security and river biodiversity. Nature 2010, 467, 555-561. [CrossRef] [PubMed]

3. Berger, E.; Haase, P.; Oetken, M.; Sundermann, A. Field data reveal low critical chemical concentrations for river benthic invertebrates. Sci. Total Environ. 2016, 544, 864-873. [CrossRef] [PubMed]

4. Carpenter, S.R.; Stanley, E.H.; Zanden, M.J.V. State of the world's freshwater ecosystems: Physical, chemical, and biological changes. Annu. Rev. Environ. Res. 2011, 36, 75-99. [CrossRef]

5. Allan, J.D. Landscapes and riverscapes: The influence of land use on stream ecosystems. Annu. Rev. Ecol. Evol. Syst. 2004, 35, 257-284. [CrossRef]

6. Richter, B.D.; Mathews, R.; Harrrison, D.L.; Wigington, R. Ecologically sustainable water management: Managing river flows for ecological integrity. Ecol. Appl. 2003, 13, 206-224. [CrossRef]

7. King, R.S.; Baker, M.E. Considerations for analyzing ecological community thresholds in response to anthropogenic environmental gradients. J. N. Am. Benthol. Soc. 2010, 29, 998-1008. [CrossRef]

8. Forio, M.A.E.; Goethals, P.L.M.; Lock, K.; Asio, V.; Bande, M.; Thas, O. Model-based analysis of the relationship between macroinvertebrate traits and environmental river conditions. Environ. Model. Softw. 2018, 106, 57-67. [CrossRef]

9. Baker, M.E.; King, R.S. A new method for detecting and interpreting biodiversity and ecological community thresholds. Meth. Ecol. Evol. 2010, 1, 25-37. [CrossRef]

10. Wallace, A.; Biastoch, R. Detecting changes in the benthic invertebrate community in response to increasing chloride in streams in Toronto, Canada. Freshw. Sci. 2016, 35, 353-363. [CrossRef]

11. Schroder, M.; Sondermann, M.; Sures, B.; Hering, D. Effects of salinity gradients on benthic invertebrate and diatom communities in a German lowland river. Ecol. Indic. 2015, 57, 236-248. [CrossRef]

12. Kovalenko, K.E.; Brady, V.J.; Brown, T.N.; Ciborowski, J.J.H.; Danz, N.P.; Gathman, J.P.; Host, G.E.; Howe, R.W.; Johnson, L.B.; Niemi, G.J.; et al. Congruence of community thresholds in response to anthropogenic stress in great lakes coastal wetlands. Freshw. Sci. 2014, 33, 958-971. [CrossRef] 
13. King, R.S.; Baker, M.E. Use, misuse, and limitations of threshold indicator taxa analysis (titan) for natural resource management. In Application of Threshold Concepts in Natural Resource Decision Making; Springer: New York, NY, USA, 2014.

14. Arias-Hidalgo, M.E. A Decision Framework for Integrated Wetland-River Basin Management in a Tropical and Data Scarce Environment; Delft University of Technology: Delft, The Netherlands, 2012.

15. Andres, C.B. Sedimentation Processes at the Confluence of the Daule and Babahoyo Rivers, Guayaquil, Ecuador. El Palmar Island; The University of Birmingham: Birmingham, UK, 2009.

16. Waite, P.J. Competition for Water Resources of the Rio Guayas, Ecuador, Optimal Allocation of Water Resources; IAHS: Exeter, UK, 1982.

17. Madonado, M.E.S. Remote Sensing Based Hydrologic Modeling in the Babahoyo River Sub-Basin for Water Balance Assessment; University of Twente: Enschede, The Netherlands, 2011.

18. Alvarez-Mieles, G.; Irvine, K.; Griensven, A.V.; Arias-Hidalgo, M.; Torres, A.; Mynett, A.E. Relationships between aquatic biotic communities and water quality in a tropical river-wetland system (Ecuador). Environ. Sci. Policy 2013, 34, 115-127. [CrossRef]

19. Forio, M.A.E.; Landuyt, D.; Bennetsen, E.; Lock, K.; Nguyen, T.H.T.; Ambarita, M.N.D.; Musonge, P.L.S.; Boets, P.; Everaert, G.; Dominguez-Granda, L.; et al. Bayesian belief network models to analyse and predict ecological water quality in rivers. Ecol. Model. 2015, 312, 222-238. [CrossRef]

20. Damanik-Ambarita, M.N.; Lock, K.; Boets, P.; Everaert, G.; Nguyen, T.H.T.; Forio, M.A.E.; Musonge, P.L.S.; Suhareva, N.; Bennetsen, E.; Landuyt, D.; et al. Ecological water quality analysis of the Guayas river basin (Ecuador) based on macroinvertebrates indices. Limnol. Ecol. Manag. Inland Waters 2016, 57, 27-59. [CrossRef]

21. Forio, M.A.E.; Mouton, A.; Lock, K.; Boets, P.; Nguyen, T.H.T.; Damanik Ambarita, M.N.; Musonge, P.L.S.; Dominguez-Granda, L.; Goethals, P.L.M. Fuzzy modelling to identify key drivers of ecological water quality to support decision and policy making. Environ. Sci. Policy 2017, 68, 58-68. [CrossRef]

22. Gelati, E.; Madsen, H.; Rosbjerg, D. Stochastic reservoir optimization using el nino information: Case study of Aaule Peripa, Ecuador. Hydrol. Res. 2011, 42, 413-431. [CrossRef]

23. Arriaga, L. The daule-peripe dam project, urban development of guayaquil and their impact on shrimp mariculture. In A Sustainable Shrimp Mariculture Industryfor Ecuador; The University of Rhode Island: Kingston, RI, USA, 1989.

24. CELEC. Revista 25 anos de la Presa Daule-Peripa. Available online: http:/ / www.Hidronacion.org (accessed on 25 October 2016).

25. Camposano, D.E.M. Predicting River Concentrations of Pesticides from Banana Plantations under Data-Poor Conditions. Ph.D. Thesis, Ghent University, Gent, Belgium, June 2004.

26. USEPA. Volunteer Stream Monitoring: A Methods Manual. Available online: http://www.water-research. net/Waterlibrary/Lake/STREAM.PDF (accessed on 19 November 2017).

27. Gabriels, W.; Lock, K.; De Pauw, N.; Goethals, P.L.M. Multimetric macroinvertebrate index flanders (mmif) for biological assessment of rivers and lakes in Flanders (Belgium). Limnol. Ecol. Manag. Inland Waters 2010, 40, 199-207. [CrossRef]

28. Domínguez, E.; Fernández, H.R. Macroinvertebrados Bentónicos Sudameri-Canos: Sistemática y Biología; Fundación Miguel Lillo: Tucumán, Argentina, 2009.

29. Dominguez-Granda, L.; Lock, K.; Goethals, P. Using multi-target clustering trees as a tool to predict biological water quality indices based on benthic macroinvertebrates and environmental parameters in the Chaguana watershed (Ecuador). Ecol. Inform. 2011, 6, 303-308. [CrossRef]

30. Mereta, S.T.; Boets, P.; Meester, L.D.; Goethals, P.L.M. Development of a multimetric index based on benthic macroinvertebrates for the assessment of natural wetlands in southwest Ethiopia. Ecol. Indic. 2013, 2013, 510-521. [CrossRef]

31. Everaert, G.; Neve, J.D.; Boets, P.; Dominguez-Granda, L.; Mereta, S.T.; Ambelu, A.; Hoang, T.H.; Goethals, P.L.M.; Thas, O. Comparison of the abiotic preferences of macroinvertebrates in tropical river basins. PLoS ONE 2014, 9, e108898. [CrossRef] [PubMed]

32. Forio, M.A.E.; Lock, K.; Radam, E.D.; Bande, M.; Asio, V.; Goethals, P. Assessment and analysis of ecological quality, macroinvertebrate communities and diversity in rivers of a multifunctional tropical island. Ecol. Indic. 2017, 77, 228-238. [CrossRef] 
33. Sharifinia, M.; Mahmoudifard, A.; Namin, J.I.; Ramezanpour, Z.; Yap, C.K. Pollution evaluation in the shahrood river: Do physico-chemical and macroinvertebrate-based indices indicate same responses to anthropogenic activities? Chemosphere 2016, 159, 584-594. [CrossRef] [PubMed]

34. Zuniga, M.C.; Cardona, W. Water quality and environmental flow bioindicators. In Environmental Flow: Concepts, Experiences and Challenges; Del Valle University: Cali, Colombia, 2009.

35. Zuur, A.F.; Ieno, E.N.; Elphick, C.S. A protocol for data exploration to avoid common statistical problems. Meth. Ecol. Evol. 2010, 1, 3-14. [CrossRef]

36. Šmilauer, P.; Lepš, J. Multivariate Analysis of Ecological Data Using Canoco; Cambridge University Press: Cambridge, UK, 2014.

37. Paliy, O.; Shankar, V. Application of multivariate statistical techniques in microbial ecology. Mol. Ecol. 2016, 25, 1032-1057. [CrossRef] [PubMed]

38. Ter Braak, C.J.F.; Verdonschot, P.F.M. Canonical correspondence analysis and related multivariate methods in aquatic ecology. Aquat. Sci. 1995, 57, 255-289. [CrossRef]

39. Oksanen, J.; Blanchet, F.G.; Kindt, R.; Legendre, P.; Minchin, P.R.; O’Hara, R.B.; Simpson, G.L.; Solymos, P.; Stevens, M.H.H.; Wagner, H. Package 'Vegan'. Available online: https:/ / cran.R-project.Org,https:/ / github. Com/vegandevs/vegan (accessed on 5 January 2016).

40. Zar, J.H. Biostatistical Analysis; Northern Illinois University: DeKalb, IL, USA, 2010.

41. Signorell, A. Desctools: Tools for Descriptive Statistics. R Package Version 0.99.17. Available online: https:/ / cran.r-project.org/web/packages/DescTools/index.html (accessed on 5 January 2016).

42. Baker, M.; King, R.; Kahle, D. Titan2: Threshold Indicator Taxa Analysis. Available online: https:/ / cran.Rproject.Org/package=titan2 (accessed on 20 January 2016).

43. Käiro, K.; Möls, T.; Timm, H.; Virro, T.; Järvekülg, R. The effect of damming on biological quality according to macroinvertebrates in some Estonian streams, Central-Baltic Europe: A pilot study. River Res. Appl. 2011, 27, 895-907. [CrossRef]

44. Selvanayagam, M.; Abril, R. Water quality assessment of piatua river using macroinvertebrates in Puyo, Pastaza, Ecuador. Am. J. Life Sci. 2015, 3, 167-174. [CrossRef]

45. Timm, H.; Kairo, K.; Molsa, T.; Virro, T.; Henn Timma, K.K. An index to assess hydromorphological quality of estonian surface waters based on macroinvertebrate taxonomic composition. Limnol. Ecol. Manag. Inland Waters 2011, 41, 398-410. [CrossRef]

46. Theodoropoulos, C.; Aspridis, D.; Iliopoulou-Georgudaki, J. The influence of land use on freshwater macroinvertebrates in a regulated and temporary mediterranean river network. Hydrobiologia 2015, 751, 201-213. [CrossRef]

47. Rawi, C.S.M.; Al-Shami, S.A.; Madrus, M.R.; Ahmad, A.H. Biological and ecological diversity of aquatic macroinvertebrates in response to hydrological and physicochemical parameters in tropical forest streams of Gunung Tebu, Malaysia: Implications for ecohydrological assessment. Ecohydrology 2013, 7, 496-507. [CrossRef]

48. Nelson, S.M.; Lieberman, D.M. The influence of flow and other environmental factors on benthic invertebrates in the Sacramento river, USA. Hydrobiologia 2002, 489, 117-129. [CrossRef]

49. Brooks, A.J.; Haeusler, T.; Reinfelds, I.; Williams, S. Hydraulic microhabitats and the distribution of macroinvertebrate assemblages in riffles. Freshw. Biol. 2005, 50, 331-344. [CrossRef]

50. Hausmann, S.; Charles, D.F.; Gerritsen, J.; Belton, T.J. A diatom-based biological condition gradient approach for assessing impairment and developing nutrient criteria for streams. Sci. Total Environ. 2016, 562, 914-927. [CrossRef] [PubMed]

51. Huanga, W.; Mukherjeea, D.; Chen, S. Assessment of Hurricane Ivan impact on chlorophyll-a in Pensacola bay by MODIS $250 \mathrm{~m}$ remote sensing. Mar. Pollut. Bull. 2011, 62, 490-498. [CrossRef] [PubMed]

52. Porter, S.D.; Mueller, D.K.; Spahr, N.E.; Munn, M.D.; Dubrovsky, N.M. Efficacy of algal metrics for assessing nutrient and organic enrichment in flowing waters. Freshw. Biol. 2008, 53, 1036-1054. [CrossRef]

53. Theodoropoulos, C.; Vourka, A.; Stamou, A.; Rutschmann, P.; Skoulikidis, N. Response of freshwater macroinvertebrates to rainfall-induced high flows: A hydroecological approach. Ecol. Indic. 2017, 73, 432-442. [CrossRef]

54. Li, F.; Cai, Q.; Fu, X.; Liu, J. Construction of habitat suitability models for benthic macroinvertebrate and their applications to instream environmental flows: A case study in Xiangxi river of three gorges reservior region, China. Prog. Nat. Sci. 2009, 19, 359-367. [CrossRef] 
55. Wang, Z.-Y.; Xu, M. Problems and researches on eco-hydraulics and eco-sedimentation. In River Flow; Taylor \& Francis Group: London, UK, 2012.

56. Nolte, U.; Oliveira, M.J.D.; Stur, E. Seasonal, discharge-driven patterns of mayfly assemblages in an intermittent neotropical stream. Freshw. Biol. 1997, 37, 333-343. [CrossRef]

57. Nguyen, T.H.T.; Boets, P.; Lock, K.; Ambarita, M.N.D.; Forio, M.A.E.; Musonge, P.S.L.; Dominguez-Granda, L.E.; Hoang, T.H.T.; Everaert, G.; Goethals, P. Habitat suitability of the invasive water hyacinth and its relation to water quality and macroinvertebrate diversity in a tropical reservoir. Limnologica 2015, 52, 67-74. [CrossRef]

58. Gerebizza, E. The Daule Peripa Project. Available online: http://eurodad.org/uploadedfiles/whatsnew/ reports/the\%20daule\%20peripa\%20projectcrbm.pdf (accessed on 15 September 2016).

59. Damanik-Ambarita, M.N.; Everaert, G.; Forio, M.A.E.; Nguyen, T.H.T.; Lock, K.; Musonge, P.L.S.; Suhareva, N.; Dominguez-Granda, L.; Bennetsen, E.; Boets, P.; et al. Generalized linear models to identify key hydromorphological and chemical variables determining the occurrence of macroinvertebrates in the Guayas river basin (Ecuador). Water 2016, 8, 297. [CrossRef]

60. Deknock, A.; De Troyer, N.; Houbraken, M.; Dominguez-Granda, L.; Nolivos, I.; Van Echelpoel, W.; Forio, M.A.E.; Spanoghe, P.; Goethals, P. Distribution of agricultural pesticides in the freshwater environment of the Guayas river basin (Ecuador). Sci. Total Environ. 2019, 646, 996-1008. [CrossRef]

61. Aude, E.; Tybirk, K.; Bruus Pedersen, M. Vegetation diversity of conventional and organic hedgerows in Denmark. Agric. Ecosyst. Environ. 2003, 99, 135-147. [CrossRef]

62. Castillo, L.E.; Martínez, E.; Ruepert, C.; Savage, C.; Gilek, M.; Pinnock, M.; Solis, E. Water quality and macroinvertebrate community response following pesticide applications in a banana plantation, Limon, Costa Rica. Sci. Total Environ. 2006, 367, 418-432. [CrossRef] [PubMed]

63. Arthington, A.H.; Bunn, S.E.; Poff, N.L.; Naiman, R.J. The challenge of providing environmental flow rules to sustain river ecosystems. Ecol. Appl. 2006, 16, 1311-1318. [CrossRef]

64. Acreman, M.C.; Dunbar, M.J. Defining environmental river flow requirements-A review. Hydrol. Earth Sci. 2004, 8, 861-876. [CrossRef]

65. Troyer, N.D.; Mereta, S.T.; Goethals, P.L.M.; Boets, P. Water quality assessment of streams and wetlands in a fast growing East African city. Water 2016, 8, 123. [CrossRef]

66. Nolivos, I.; Villacis, M.; Vázquez, R.; Mora, D.E.; Domínguez-Granda, L.; Hampel, H.; Velarde, E. Challenges for a sustainable management of Ecuadorian water resources. Sustain. Water Qual. Ecol. 2015, 6, 101-106. [CrossRef]

67. Wallace, J.B.; Webster, J.R. The role of macroinvertebrates in stream ecosystem function. Annu. Rev. Entomol. 1996, 41, 115-139. [CrossRef] [PubMed]

68. Diehl, S. Fish predation and benthic community structure-The role of omnivory and habitat complexity. Ecology 1992, 73, 1646-1661. [CrossRef] 